\title{
DIKOTOMI HADIS AHAD-MUTAWATIR; MENURUT PANDANGAN ALI MUSTAFA YAQUB
}

\author{
Abdul Mutualli \\ Fakultas Ushuluddin Filsafat dan Politik UIN Alauddin Makassar \\ Muthawalli27@gmail.com
}

\section{Abstrak}

Dewasa ini orang banyak memperdebatkan kehujjahan hadis do'if, apakah boleh dijadikan landasan beramal atau malah sebaliknya. Mereka melupakan hadis ahad yang jauh pada abad kedua sudah menjadi perdebatan diantara ulama Mu'tazilah dan Ahlusunnah. Al-nadham sebagai ulama dari kelompok Mu'tazilah menganggap bahwa hadis ahad bersifat dhan sehingga tidak dapat dijadikan hujjah dalam hal aqidah, mereka menolak adanya penggunaan hadis ahad. Padahal periwayatan secara ahad tidak bisa terelakkan karena periwayatan hadis pada masa Nabi dengan cepat tersebar ke masyarakat. Para sahabat sangat antusias dalam menerima dan menyampaikan secara bebas hadis yang diterima dari Rasulullah saw. tanpa melihat berapa jumlah jalur orang yang menyampaikannya. Periwayatan secara ahad ataupun mutawatir tidak menjadi perhatian. Untuk mengkaji masalah tersebut maka penulis menggunakan pemikiran Ali Mustafa Yaqub dalam membahas "Dikotomi hadis ahad terdapat bukunya yang berjudul Kritik Hadis. Penting untuk memahami perdebatan tentang hadis ahad tersebut guna menambah wawasan. Menurut analisis penulis hadis ahad tidak bisa ditolak dan tidak dijadikan hujjah dalam masalah akidah, ketika ini dilakukan konsekuensinya banyak hadis yang akan ditolak, seperti tentang syurga dan beraka, dajjal, siksa kubur, mizan di akhirat dll. Hemat penulis adalah pembagian hadis ahad tetap ada dalam disiplin ilmu hadis namun bukan berarti pembagian ini akan menjatuhkan derajat hadis ahad.

Kata Kunci: Dikotomi, Hadis, Ahad, Mutawatir

\section{Pendahuluan.}

Kodifikasi hadis menggunakan waktu yang cukup lama, 
Kodifikasi hadis resmi dilakukan sejak abad ke dua hijriah masa khalifah Umar Bin Abdul Aziz jauh setelah wafatnya Nabi Muhammad. ${ }^{1}$ Inilah yang menjadi senjata para orientalis meyerang hadis -hadis dari segi kualitas.

Hadis pada masa Nabi dengan cepat tersebar ke masyarakat. ${ }^{2}$ Para sahabat sangat antusias dalam menerima dan menyampaikan hadis yang diterimanya dari Nabi, sehingga inilah yang menyebabkan hadis cepat tersebar luas dikalangan sahabat meskipun di masa Nabi hadis belum resmi dibukukan. Nabi hidup ditengah-tengah sahabat mereka bertemu dan bergaul dengan Nabi kapan saja bukan hanya di dalam majelis saja akan tetapi mereka bisa bergaul secara bebas di luar majelis, mereka bebas bertanya apa saja dimanapu ia bertemu dengan Nabi. ${ }^{3}$

Dengan melihat dari kacamata sejarah bahwa para sahabat dengan mudahnya menerima dan menyampaikan hadis, maka periwayatan hadis dengan jalur sedikit besar kemungkinan terjadi. Ada kemungkinan pernah seorang sahabat yang bertemu dengan Nabi di luar majelis, kemudian sahabat tersebut mempertanyakan suatu masalah kemudian dijawab oleh Nabi, setelah itu sahabat tersebut dikemudian waktu juga menyampaikan kepada sahabat lain yang diterimanya dengan cara individu dari Nabi. ${ }^{4}$

Pembagian hadis bedasarkan jalur periwayatan dibagi

1 Tengku Muhammad Hasbi ash-shiddieqy, Sejarah Dan Pengantar Ilmu Hadits (Cet;II: Semarang: PT Pustaka Rizki Putra, 2009) h. 52-53.

2 M. Syuhudi Ismail, Kaedah Kesahihan Hadis (Cet; II; Jakarta: PT Bulan Bintang, 1995) h. 36.

3 Tengku Muhammad Hasbi ash-shiddieqy, Sejarah Dan Pengantar Ilmu Hadits, h. 26.

4 Salamah Noorhidayati, Kritik Teks Hadis (Cet: I; Yogyakarta: Dialektika, 2017), h. 26-27. 
menjadi dua yakni, ahad dan mutawatir. ${ }^{5}$ pembagian inilah yang menjadi konfersi di kalangan ulama sekaligus ada yang mengangggapnya bid'ah, yang tetap membagi keduanya dan ada pula yang melemahkan hadis ahad dengan anggapan hadis ahad tidak bisa dijadikan hujjah dalam hal akidah. Hadis sangat penting untuk diteliti keabsahannya, khususnya hadis ahad yang menjadi polemik di masyarakat. Karena hadis merupakan bagian yang penting dalam pokok ajaran islam setelah al-quran. Penelitian ini sangat penting agar dalil-dalil hadis ahad ini dapat dipertanggung jawabkan sampai ke Rasulullah. ${ }^{6}$

\section{Biografi Ali Mustafa Yaqub}

Ali Mustafa Yaqub merupakan salah satu tokoh Muhaddisin yang karyanya banyak dijadikan rujukan. Beliau lahir di desa Kemiri, Kecamatan Subah, Kabupaten Batang, Provinsi Jawa Tengah. Tanggal 2 Maret 1952. Nama belakang beliau adalah nama ayahnya, jadi beliau biasa di panggi dengan singkatan Al-Fabia yakni Ali Mustafa Yaqub bin Yaqub. ${ }^{7}$

Beliau terlahir dalam lingkungan keluarga yang taat beragama dan termasuk dalam ekonomi yang serba kecukupan. Ali Mustafa Yaqub tidak pernah merasa kekurangan biaya sehari-seharinya selalu di penuhi, namun beliau tidak pernah membangkan ataupun berpoya-poya terhadap orang tuanya karena fasilitas yang diberikan melainkan Ali Mustafa Yaqub tumbuh sebagai anak yang patuh dan agamawan, karena orang

5 Fatchur Rahman, ikhtishar Mushthalahu'l Hadits (Cet: I; Bandung: PT alm'arif, 1974), h. 78

${ }^{6}$ M. Syuhudi Ismail, Metode Penelitian Hadis Nabi (Cet: I; Jakarta: PT Bulan Bintang, 1992), h. 10.

${ }^{7}$ Ali Mustafa Yaqub, Islam Masa Kini (Cet: I; Jakarta: Pustaka Firdaus, 2001), h. 9. 
tuanganya memberikan didikan agama yang baik. ${ }^{8}$

Ayah beliau adalah muballig yang terkenal pada masanya dan merupakan imam-imam masjid yang ada di Jawa Tengah, ibunda Ali Mustafa Yaqub juga sebagai ustazdah dan ibu rumah tangga,m namanya ibunya ialah $\mathrm{Hj}$ Zulaikah ${ }^{9}$.Sejak kecil Ali Mustafa Yaqub tidak jauh berbeda dengan anak-anak lainnya yang serba berkecukupan, sejak umur tujuh tahun beliau berdekolah di Sekolah Rakyat pada tahun 1961 sampai 1966.10 Di sekolah Ali Mustafa Yaqub banyak di senangi oleh temantemannya karena ia adalah murid yang tergolong cerdas.

Setelah menempuh pendidikan di sekolah rakyat selama kurang lebih 6 tahun, Ali Mustafa Yaqub melanjutkan pendidikannya di SMP di daerahnya. Obsesinya Ali Mustafa Yakub untuk terus menempuh pendidikan di sekolah umum ternyata harus kandas setelah tammat SMP. Karena setelah tammat di sekolah menengah pertama ia harus mengikut arahan orang tuanya untuk menuntut ilmu Agama di pondok pesantren. Sebagai anak yang taat dan faham tentu saja beliau nurut dengan kemauan Ayahnya.

Pada tahun 1966 Ali Mustafa Yaqub mulai Mondok mencari keweruh ${ }^{11}$ di pondok pesantren Seblak Jombang sampai tingkat Tsanawiyah(Aliyah). Kemudian 1996 Ali Mustafa Yaqub melanjutkan pendidikannya di pesantren Tebuireng Jombang

8 Dewi Anggraini dan Sitti Suhartinah, "Toleransi Antara Ummat Beragama Presfektif Alimustafa Yaqub", Studi Al-Qur'an Membangung Tradisi Berfikir Al-Qur'an14, no. 1 (2018), h. 61-62.

${ }^{9} \mathrm{Hj}$ Zulaikah ibunda AliMustafa Yaqub wafat yang sehari-harinya menjadi ustazdah wafat pada tahun 1996.

10 Dewi Anggraini dan Sitti Suhartinah, “Toleransi Antara Ummat Beragama Presfektif Alimustafa Yaqub", Studi Al-Qur'an Membangung Tradisi Berfikir Al-Qur'an, h. 62.

11 Keweruh adalah salah satu kosa kata bahasa jawa yang berasal dari kata kawruh yang berarti pengetahuan. 
yang jaraknya hanya beberapa ratus meter saja dari lokasi pesantren Seblak. Sambil beliau mondok Ali Mustafa Yaqub ini melanjutkan pendidiknnya ke jenjang perkuliahan.

Awalnya beliau ingin mengambil jurusan kedokteran hingga Akhirnya pada beliau memutuskan kuliah di fakultas Syari'ah Universitas Hasyim Asy'ari. Di samping beliau belajar formal Ali Mustafa yaqub juga belajar non formal di pondok pesantren Tebuireng Jombang. Di pesantren tersebut Ali Mustafa Yaqub belajar kitab-kitab kuning di bawah asuhan para kiai sepuh ${ }^{12}$ antara lain almarhum K.H. Idris Kamali, al-marhum K.H. Adlan Ali, al-marhum K.H. Shobari dan al-musnid K.H. Syansuri Badawi. Bukan hanya belajar akan tetapi ali Mustafa Yaqub juga menjadi tenaga pengajar Bahas Arab hingga awal 1976.

Semangat Ali Mustafa Yaqub dalam menuntut ilmu tidak pernah surut di buktikan dengan setelah beliau mendapatkan gelar Sarjananya di Universitas Hasyim Asy'ari ia kembali melanjutkan pendidikannya di tanah Arab Saudi. Tepatnya di Fakultas Syari'ah Universitas Islam Imam Muhammad bin Saud, hingga belau meraih gelar Licence (lc).

Pada tahun 1980 Ali Mustafa Yaqub melanjutkan pendidikan pasca di di kota yang sama pada Universitas King Saud dan mengambil jurusan Ilmu Tafsirdan Hadis. di Universitas inilah Ali Mustafa Yaqub bertemu dengan salah satu pakar hadis yakni Muhammad Mustafa Al-Azami. setelah beliau mendapatkan gelar Masternya tahun 1985 beliau kembai

\footnotetext{
12 Sepuh adalah salah satu kosa kata bahasa jawa yang umum digunakan untuk memberikan julukan kepada orang yang dituakan. Sepuh artinya tua karena usianya namun bisa juga berarti pinisepuh artinya orang di tuakan. Dalam tradisi jawa sebutan sepuh ini ditujukan untuk orang-orang yang memiliki jabatan sosial tertentu tokoh agama, pimpinan lembaga masyarakat dll.
} 
ketanah air.

Setelah tiba di Indonesia Ali Mustafa Yaqub mengabdikan ilmunya di berbagai perguruan tinggi salah satunya Institut Ilmu Alquran (IIQ), Institut Studi Ilmu Alquran (ISIQ/PTIQ), Sekolah Tinggi Ilmu Dakwah (STIDA), dan IAIN Syarif Hidayatullah Jakarta, dan pada tahun 1989 Ali Mustafa Yaqub bersama dengan keluarganya mendirikan pesantren di desa kelahirannya bernama Darussalam. Masi banyak lagi prestasi-prestasi yang pernah di lalui oleh beliau sebagai Aktifis Tanah Air.

\section{Pengertian Hadis Ahad dan mutawatir}

Dilihat dari segi banyak atau sedikitnya penukilan khabar yang menjadi sumber berita terbagi menjadi dua macam yakni, hadis ahad dan mutawatir.

1. Hadis Mutawatir.

a) Penegertian Hadis Mutawatir.

mutawatir menurut bahasa berasal dari kata متابع atau maksudnya yang datang beriringan antara satu dengan lainnya dengan tidak ada perselangannya ${ }^{13}$. Atau datang sesuatu secara berturut-turut secara bergantian tanpa adanya yang mencela. Yang dimaksudkan di sini adalah mutawatir mengandung penegertian yang bersifat terus menerus atau kontinyu yang berturut-turut tanpa adanya yang mencela dan menghalangi komunitas itu. ${ }^{14}$

Secara istilah mutawatir adalah Hadis yang di diriwayatkan oleh rawi yang jumlahnya banyak, diterima secara pancra indera dan secara adat dan dan kebiasaan pada masa itu

${ }^{13}$ M. Syuhudi Ismail, Pengantar Ilmu Hadits (Cet: II; Bandung: Angkasa, 1994), h. 135.

14 Idri, Hadis dan Orientalis (Cet: I; Depok: PT Balebat Dedikasi Perima, 2017), h. 308 
tidak mungkin mereka sepakat untuk berdusta. ${ }^{15}$ Rawi yang banyak harus terdapat disetiap tingkatan tabaqat. ${ }^{16}$

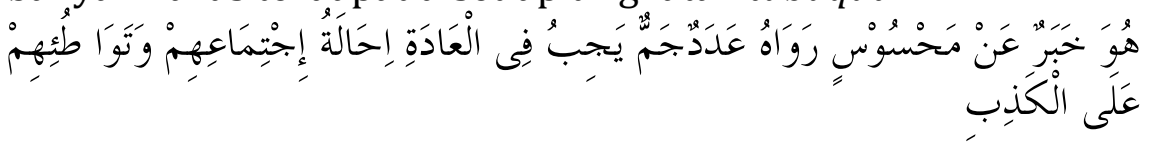

Artinya:

Suatu hadis hasil tanggapan dari panca indera, yang diriwayatkan oleh sejumlah besar rawi, yang menurut adat kebiasaan mustahil mereka berkumpul dan sepakat berdusta.

Para ulama berbeda pendapat mnegenai pengharusan adanya indikator panca indera, ada sebagian ulama yang tidak mengharuskan periwayatan melalui pancaindera. ${ }^{17}$ Adapun pendefinisian hadis mutawatir dikalangan ulama dengan beragam presepsi yakni, menurut Mahmud al-Tahan, definisi hadis mutawatir adalah hadis yang diriwayatkan oleh banyak periwayat yang menurut adat kebiasaan mustahil mereka sepakat berdusta. ${ }^{18}$

Muhammad 'Ajjaj al-Hatib hadis mutawatir adalah hadis yang diriwayatkan oleh sejumlah periwayat yang menurut adat kebiasaan mereka sepakat untuk berdusta dari seetiap rawi yang ada dan dari setiap tabaqat tidak kurang dari standarisasi hadis mutawatir. ${ }^{19}$ Menurut Nur al-Din 'Itr hadis mutawatir adalah hadis yang diriwayatkan oleh sejumlah orang yang tidak mungkin mereka sepakat untuk berdusta sampai akhir sanad. Dan hadis yang diriwayatkan harus sesuai dengan pengamatan

15 Ahmad S Marzuqi, terjemahan Mushthalah Al Hadits (Cet:V; Jogjakarta: Media Hidayah, 2008), h. 19.

16Fatchur Rahman, ikhtishar Mushthalahu'l Hadits, h. 78.

17M. Syuhudi Ismail, Pengantar Ilmu Hadits, h. 135.

18 Mahmud al-Tahan, Terj. Bahak Asadullah, Mustalah Al-Hadis/: Dasar-dasar Ilmu Hadits (Cet: II; Jakarta Timur: Ummul Qura, 2017), h. 29. Lihat juga pada Idri, Hadis dan Orientalis, h. 308.

${ }^{19}$ Idri, Hadis dan Orientalis, h. 308. 
pancaindera. ${ }^{20}$

Menurut Muhammad Muhammad Abu Suyhbah hadis mutawatir adalah hadis yang diriwayatkan oleh beberapa orang yang menurut akal sehat dan adat kebiasaan mereka mustahil untuk berdusta tentang hadis yang diriwayatkan, dari sejumlah periwayat sepadan dari sanad awal sampai akhir dengan syarat tidak kurang disetiap generasi dan sandaran yang digunakan berdasarkan yang didapatkan dengan indera, seperti disaksikan, didengar, dll. ${ }^{21}$

Dari berbagai opini para pakar hadis yang telah dituliskan sangatlah beragam namun pada esensinya mempunyai titik temu yang sama. Yakni berujung pada kesimpulan hadis yang disampaikan oleh banyak periwayat yang di setiap generasi selalu mencapai standarisasi kriteria hadis mutawatir. Mereka berkumpul menurut adat dan kebiasaan mustahil mereka berdusta, dan apa yang disampaikan diterima dengan pancaindera.

b) Kriteria dan syarat hadis mutawatir

Berdasarkan berbagai pengertian maka syarat dan kriteria hadis mutawatir yakni:

1) Periwayatan yang disampaikan oleh rawi-rawi tersebut harus berdasarkan tanggapan pancaindera.

2) Jumlah rawi-rawi harus mencapai satu kesatuan yang tidak memungkinkan mereka sepakat unutuk berbohong.

3) Adanya keseimbangan jumlah rawi-rawi dalam setiap tabaqat pertama dengan tabaqat- tabaqat selanjutnya. Adapun contoh hadis mutawatir yakni:

${ }^{20}$ Nur al-Din 'I, Terj. Mujiyo, Manhaj al-Naqad fi 'Ulum al-Hadis/ alNabawi: 'Ulum Hadis (Cet: V; Bandung: PT Remaja Sosdakarya, 2017), h. 428. ${ }^{21}$ Idri, Hadis dan Orientalis, h. 309. 


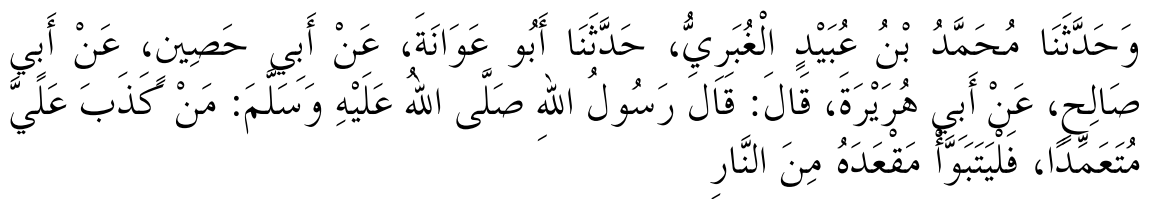

Artinya:

Telah menceritakan kepada kami Muhammad bin Ubaid alGhubari telah menceritakan kepada kami Abu Awanah dari Abu Hashin dari Abu Shalih dari Abu Hurairah dia berkata, "Rasulullah shallallahu 'alaihi wasallam bersabda: "Barangsiapa berdusta atas namaku maka hendaklah dia menempati tempat duduknya dari neraka."22

2. Hadis Ahad

a) Pengertian Hadis Ahad

Hadis Ahad $^{23}$ adalah hadis yang tidak memenuhi syaratsyarat hadis mutawatir ${ }^{24}$. Hadis Ahad adalah selain dari hadis mutawatir. ${ }^{25} \mathrm{Al}$-ahad merupakan kata jamak dari ahad yang berarti satu ${ }^{26}$. Hadis Ahad adalah hadis yang diriwayatkan oleh satu orang.Hadis Ahad adalah hadis yang bersumber dari Nabi yang menurut periwayatanya tidak sampai kepada kriteria hadis mutawatir. dan standarisasi jalur rawi berlaku pada setiap lapisan generasi.

b) Pembagian Hadis Ahad

Hadis Ahad ulama sepakat menjadi tiga bagian yakni,

22 Muslim bin al-Hajjaj Abu al-Husain al-Qusyairi al-Naisaburi, Sahi@h Muslim, Juz I (Cet. I; Saudiy, Riyad: Dar Taibah li al-Nasyr wa alTawazzu', 1427 H/ 2006 M), h. 10.

23 Ahad berasal dari bahasa arab yakni احد yang berarti satu atau seseorang. lihat Ahmad Warson, Al Munawwir Kamus Arab-Indonesia (Cet: II; Surabaya: Pustaka Progressif, 1997), h. 8.10-11.

24Fatchur Rahman, ikhtishar Mushthalahu'l Hadits, h. 85.

${ }^{25}$ Muhammad bin Salih al-'Us|aimin, Mustalah Al-Hadis/ (Cet: I; Mesir al-'Arabiyah: Dar Ibnu Jauz|iyah al-Qohiroh, 2006), h.

26 Mahmud al-Tahan, Terj. Bahak Asadullah, Mustalah Al-Hadis/: Dasar-dasar Ilmu Hadits, h. 32. 
masyhur, aziz dan garib:

1) Masyhur adalah hadis yang diriwayatkan oleh tiga orang rawi atau lebih tetapi tidak sampai kepada derajat mutawatir. contoh:

Artinya:

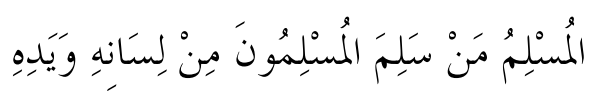

Seorang muslim tidaklah mengganggu kaum muslimin dengan lisan dan tangannya ${ }^{27}$

2) Aziz adalah hadis yang diriwayatkan oleh dua orang rawi. Contoh:

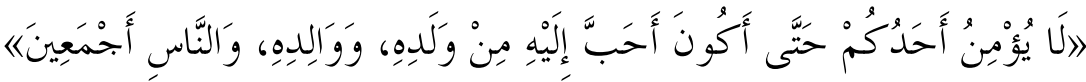
Artinya:

Salah seorang dari kalian tidak akan beriman hingga aku menjadi orang yang paling dicintainya dari pada anaknya, orang tuanya dan manusia semuanya. ${ }^{28}$

3) garib adalah hadis yang diriwayatkan oleh satu orang rawi. Contoh:

Artinya:

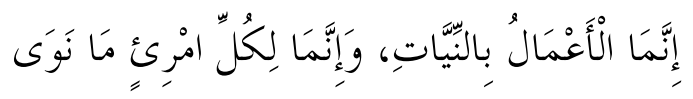

Sesungguhnya amalan itu tergantung kepada niatnya, dan bagi setiap orang akan mendapatkan sesuai apa yang telah

27 Muhammad bin Ismail Abu Abdillah al-Bukhari al-Ja'fiya, Lijami' al-Sahih al-Mukhtasar (Sahih al-Bukhari), Juz I (Qairoh: al-Muthabatu alSalafiyyu wa al-Maktabatuha; Cetakan: I; Tahun 1422), h. 11.

${ }^{28} \mathrm{Abi}$ 'Abdullah Muhammad bin Yazid al-Quzwayniy a-Syahir, Ibn Majah, Sunan Ibn Majah,Juz I (Cet. I ; Maktabah al-Ma'arif li al-Nas \hi wa alTawzi'I, Tahun 1417), h. 26. 
ia niatkan. ${ }^{29}$

Kedudukan hadis ahad ber bedah-bedah namun jumhur Ulama sepakat yang bersatatus maqbul wajib untuk di amalkan. ${ }^{30}$ Ulama juga berbedah pendapat tentang kehujjahan hadis ahad sebagai dalil aqidah, karena menganggap lemah berbeda dengan hadis mutawatir yang kuat.

\section{Pemikiran Ali Mustafa Yaqub tentang Pembagian Hadis Ahad dan mutawatir}

Setelah masa pengkodifikasian hadis selesai mulailah para ulama mengembangkan fokus kajiannya kepada ilmu-ilmu hadis . ${ }^{31}$ tidak terelakkan hingga masa sekarangpun ilmu-ilmu hadis masi terus dikembangkan oleh para pakar-pakar hadis .

1. Pernyataan Mendasar Dari Ulama Saudi Arabia

Ali Mustafa Yaqub membuka pengantar pemikirannya dengan memberikan problem masalah dengan yang di kemukakan oleh salah satu ulama yang pepoler di Arab Saudi. Syekh 'Abd al-'Aziz bin Rasyid al-Najdi ulama tersebut menuliskan dalam kitabnya yang berjudul radd Syubhat al-Ilhad 'An ahadis al-ahad, beliau mengatakan bahwa pembagian hadis menjadi ahad dan mutawatir adalah bid'ah's2.

Pada dasarnya sangat banyak ulama hadis yang sepakat

29 'Abu Daud Sulaiman ibn al-'Asy'as| ibn 'Ishaq ibn Basyir ibn Syaddad ibn 'Amru al-'Azadi al-Sijistani, Sunan 'Abi Daud, Juz II (Bairut: Jami' Haquq Hadzini al-Thaba'ah Mahfudzoh; Cetakan I; tahun 1418 H), h. 262.

${ }^{30}$ M. Syuhudi Ismail, Pengantar Ilmu Hadits, h. 158.

31 Tengku Muhammad Hasbi ash-shiddieqy, Sejarah Dan Pengantar Ilmu Hadits, h. 25. Lihat juga pada M. Syuhudi Ismail, Pengantar Ilmu Hadits, h. 124.

32 Bid'ah adalah pembaharuan ajaran agama Islam: suatu ibadah yang pada masa Nabi tidak dilakukan dan sekarang dilakukan. Lihat Tim Pustaka Phoenix, Kamus Besar Bahasa Indonesia (Cet: V; Jakarta Barat: PT Media Pustaka Phoenix, 2010), h. 126. 
dengan pendapat Syekh 'Abd al-'Aziz bin Rasyid al-Najdi, ${ }^{33}$ terutama dari kalangan yang tidak sepakat atas opini yang melemahkan hadis-hadis ahad. Dan atas problem inilah sehingga Ali Mustafa Yaqub menuliskan pendapatnya untuk melihat apakah maksud Syekh 'Abd al-'Aziz bin Rasyid al-Najdi mengatakan pembagian ahad dan mutawatir adalah bid'ah ? inilah yang hendak dikaji dalam tulisan Ali Mustafa Yaqub.

2. Konotasi Hadis Ahad-Mutawatir

Secara bahasa, kata ahad adalah sinonim dengan kata wahid yang berarti satu. ${ }^{34}$ Hadis ahad adalah hadis ahad adalah hadis yang diriwayatkan oleh satu orang dalam setiap lapisan periwatannya dan jumlah itu tidak mencapai derajat hadis mutawatir. jelas bahwa hadis ahad pada dasarnya sampai kepada Rasulullah s.a.w. oleh satu sahabat atau lebih, kemudian lanjut diriwayatkan oleh satu orang tabi'in atau lebih dan demikian seterusnya pada setiap lapisan namun tidak sampai kepada derajat mutawatir. ${ }^{35}$

Sedangkan hadis mutawatir adalah kebalikan dari hadis ahad, hadis mutawatir secara bahasa berarti berturut-turut. hadis mutawatir adalah hadis yang disampaikan oleh rawi-rawi yang banyak jumlahnya secara berturut-turut pada setiap lapisan generasi dimana menurut adat kebiasaan mereka mustahil berkumpul untuk membuat kebohongan. ${ }^{36}$ Adapun standarisasi jumlah rawi para ulama berbeda-beda dalam memberikan pendapat, namun pendapat yang umum adalah minimal sepuluh jalur dalam setiap tabaqah.

2018), h. 131.

${ }^{33}$ Ali Mustafa Yaqub, Kritik Hadis (Cet: VIII; Jakarta: Pustaka Firdaus,

34 Mahmud al-Tahan, Terj. Bahak Asadullah, Mustalah Al-Hadis/: Dasar-dasar Ilmu Hadits, h. 32.

35 Ali Mustafa Yaqub, Kritik Hadis, h. 131-132.

${ }^{36}$ Ali Mustafa Yaqub, Kritik Hadis, h. 132. 
Apabila dalam salah satu tabaqah ada yang tidak jumlah rawi hanya senbilan(tidak mencapai jumlah minimal hadis mutawatir), sekalipun tabaqah sebelum atau sesudahnya mencapai ratusan hadis tersebut tetap tidak dikategorikan hadis mutawatir. dalam artian hadis semacam ini tetap dikategorikan hadis ahad. Konotasi ini berbeda dengan pendapat umum yang mengatakan hadis ahad sebagai hadis perorangan. Sedangkan hadis mutawatir adalah hadis kolektif37. Padahal hadis yang diriwayatkan oleh sembilang orang juga termasuk kolektif. Tetapi masi tetap dikatakan hadis ahad.

3. Yakin dan Dhann

Dikotomi hadis ahad-mutawatir hanyalah dilihat dari kuantitas rawi saja. ${ }^{38}$ Walapun kendatinya berdampak pada kualitas hadis karena dianggap hadis mutawatir lebih unggul karena jumlah rawi-rawi yang meriwayatkannya lebih banyak. Karena hal inilah yang menyebabkan para ulama memberikan pengertian yang myakinkan terhadap hadis mutawatir. Sementara hadis ahad harus di uji dulu karena di anggap bersifat dhann (dugaan atau pikiran yang kuat). ${ }^{39}$

4. Aqidah harus yaqin

Atas dasar Anggapan inilah sehingga para ulama ada yang melemahkan hadis ahad ada yang berpendapat bahwa masalah-masalah aqidah harus dilandaskan atas dalil-dalil yang kuat dan meyakinkan, seperti Alquran dan hadis -hadis mutawatir saja. Sedangkan hadis ahad tidak dapat dijadikan dalil-dalil tentang aqidah. Sebagai mana dituliskan oleh Syeikh

${ }^{37}$ Kolektif maksudnya gabungan, bersama atau terpadu. Lihat Tim Pustaka Phoenix, Kamus Besar Bahasa Indonesia, h. 458.

38 Ali Mustafa Yaqub, Kritik Hadis, h. 132.

${ }^{39}$ Ali Mustafa Yaqub, Kritik Hadis, h. 132. 
Mahmud Syaltut dalam bukunya al-Islam, Aqidah wa Syari'ah. ${ }^{40}$

Setelah melihat empat tema di atas yang menjadi problem tentang kualitas dan kegunaan hadis ahad. Dalam tulisan Ali Mustafa Yaqub metode untuk menjawab masalah, beliau terlebih dahulu mengumpulkan lalu kemudian menjawab secara bersamaan berdasarkan kesimpulan dari beberapa problem yang menjadi cabang-cabang topic initi. Adapun tanggapan Ali Mustafa Yaqub sebagai berikut.

Melihat problem ulama yang melemahkan hadis ahad maka secara tidak lansung ia melemahkan banyak hal masalahmasalah akidah islam, konsekuensinya adalah ia menggusur sebagian besar aqidah ummat islam, seperti, tentang syafa'at Nabi Muhammad s.a.w di akhira, mukjizat Nabi s.a.w sifat-sifat malaikat dan jin, sifat-sifat syurga dan neraka, siksa kubur, mizan di akhiratjembatan shirat, tanda-tanda hari kiamat, datangnya dajjal dll. Semua itu akan dilemahkan. ${ }^{41}$

Atas alasan konsekuensi inilah ulama menentang dengan tegas tentang pembagian hadis ahad-mutwatir, bukan hanya itu bahkan Syekh 'Abd al-'Aziz bin Rasyid al-Najdi dengan tegas mengatakan pembagian tersebut bid'ah dan menyesatkan.

Adapun kriteria hadis sebagai dalil, sebenarnya para ulama Kususnya para ulama hadis tidak pernah mengatakan hadis ahad tidak bisa digunakan sebagai dalil-dalil aqidah. Akan tetapi mereka hanya menatakan hadis sahih dan hasan adalah hujjah dalam ajaran Agama Islam, baik dalam hal aqidah syari'ah maupun akhlaq, sedangkan hadis do'if tidak bisa dijadikan dalil kecuali atas dasar tertentu. ${ }^{42}$

Model seperti ini juga sudah terlihat pada masa sahabat,

40 Ali Mustafa Yaqub, Kritik Hadis, h. 133.

${ }^{41}$ Ali Mustafa Yaqub, Kritik Hadis, h. 133.

42 Ali Mustafa Yaqub, Kritik Hadis, h. 133. 
dimana sahabat ketika menerima dan meriwayatkan hadis tidak pernah memikirkan apakah riwayatnya akan menjadi ahad ataukah mutawatir. demikian dengan Rasulullah s.a.w juga tidak pernah mengumpulkan sahabat ketika ingin menyampaikan ajaran agama.

Dikala para sahabat dan ulama klasik tidak pernah memilah-milah hadis trus siapakah yang pertamakali memunculkan dan menolak hadis ahad sebagai dalil aqidah? Banyak tuduhan terhadap kelompok ahli ilmu qalam(mu'tazila) mereka dituduh melakukan dikotomi pembagian hadis ahadmutawatir kemudian menolak hadis ahad sebagai dalil aqidah. Namun menurut Imam Ibn Hazm(w 456 H) bahwa pada awalnya semua aliran menerima hadis sebagai hujjah. Hal itu baru terjadi ketika awal Abad ke II hijria, namun kelompok Mu'tazila sendiri tidak semua ummatnya menolak hanya sebagian kecil saja. ${ }^{43}$

Jelas sudah bahwa hanya sebagian orang yang menolak hadis ahad sebagai hujjah dalam hal aqidah. Namun bagaimana ulama membahtah pendapat Mu'tazila? Yakni sebagai berikut.

a) Alquran

Ada beberapa ayat yang dijadikan argument untuk menjadikan hadis ahad sebagai hujjah antara lain Q.S. AlTaubah/9:122.

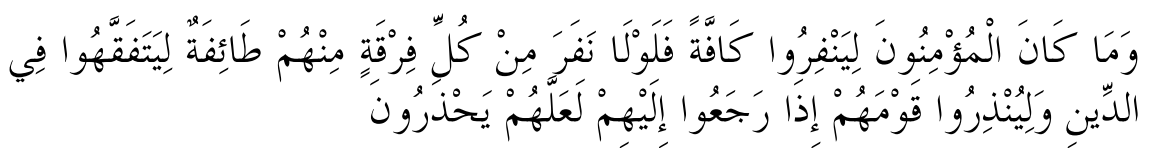

Artinya:

Dan tidak sepatutnya orang-orang Mukmin itu semuanya pergi(kemedan perang). Mengapa sebagian dari setiap golongan di antara mereka tidak pergi untuk memperdalam pengetahuan agama mereka untuk memberi peringatan

${ }^{43}$ Ali Mustafa Yaqub, Kritik Hadis, h. 134. 
kepada kaumnya apabila mereka telah kembali, agar mereka dapat menjada dirinya. ${ }^{44}$

Dalam ayat ini menggunakan kalimat "beberapa orang" ini lafal aslinya bermakna "satu atau dua orang saja" ini jelas menunjukkan bahwa belajar Agma dan menyapaikannya tidak harus rombongan.

b) Hadis Nabawi

Banya sekali hadis yang bisa dijadikan argument salah satunya yang digunakan dalam sabda Nabi "Allah akan mencerahkan wajah orang yang mendengarkan sesuatu daripadaku, kemudian ia menyampaikannya(kepada orang lain) seperti yang ia dengar" kata orang disini menggunakan kata imra'an yang yang merupakan bentuk tunggal. Jadi untuk menerima dan menyampaikan hadis Nabi boleh perorangan saja, baik yang di sampaikan masalah akidah, syari'ah maupun akhlaq. ${ }^{45}$

c) Ijma'

Peristiwa ini terjadi pada saat shalat subuh di masjid Quba' dengan menhadap kiblat ke baitul maqdis, tiba-tiba ada seorang sahabat yang berkata bahwa dirinya semalam shalat isya bersama Nabi menhadap ke ka'bah di Makkah. Tampa menanyakan jumlah periwayatnya meraka langsung shalat menhadap ke ka'bah. Padahal perkara kiblat ini sangat sensitive dalam agama islam akan tetapi berubah setelah ada yang seorang sahabat yang meriwayatkan kiblat telah diubah. ${ }^{46}$

Terjadi perbedaan pendapat yakni menurut Syekh Mamhmud Syaltut menegaskan bahwa hadis ahad tidak bisa

${ }^{44}$ Kementrian Agama RI, Al-Qur'an Tajwid dan Terjemah (Cet: 9; Jawa Barat: CV Diponegoro, 2016), h. 206.

45 Ali Mustafa Yaqub, Kritik Hadis, h. 135.

${ }^{46}$ Ali Mustafa Yaqub, Kritik Hadis, h. 135-136. 
dijadikan hujjah dalam masalah akidah. Berda dengan Syeikh bin Rasyid berpendapat bahwa dhann terpuji bisa digunakan sebagai landasan aqidah. Sebagai mana Alquran juga menggunakan dhann terpuji sebagai mana dalam Q.S. AlBaqarah ayat 45-46. Pendapat menurut Syekh Mamhmud Syaltut disini seharusnya perlu diadakan penelitian ulang sebab bertolak belakang dengan Alquran. ${ }^{47}$

\section{Kesimpulan}

Hadis ahad secara bahasa berarti satu. Sedangkan secara istilah bahwa hadis ahad merupakan hadis yang periwayatannya tidak sampai kepada derajat mutawatir pada setiap tabaqah. dalam hal ini hadis ahad dibagi menjadi tiga yakni, hadis yang diriwayatkan oleh tiga orang atau lebih tetapi tdak sampai kepada derajat mutawatir disebut masyhur, dua orang disebut 'aziz dan satu orang periwayat disebut garib. Sedangkan hadis mutawatir secara bahasa berarti berturutturut. Secara istilah hadis mutawatir adalah hadis yang diriwayatkan oleh banyak periwayat pada sietiap lapisan tabaqat, ulama secara umum sepakat standarisasi hadis mutawatir minimal 10 jalur.

Menurut Ali Mustafa Yaqub beliau tetap sepakat adanya pembagian hadis ahad-mutawatir tetap ada, sebagai salah satu ilmu hadis. namun beliau tidak sepakat ketika harus melemahkan atau bahkan sampai menghilangkan hadis ahad yang mana sebagian para ahli ilmu qalam tidak mengambil hadis ahad sebagai landasan aqidah. Penulis berasumsi bahwa Ali Mustafa Yaqub cenderung sepakat dengan Syekh 'Abd al-'Aziz bin Rasyid al-Najdi yang mengatakan dikotomi hadis ahadmutawatir bid'ah. Akan tetapi Ali Mustafa Yaqub lebih halus

${ }^{47}$ Ali Mustafa Yaqub, Kritik Hadis, h. 136-137. 
dalam mengemukakan pendapatnya menegnai titiktemu dikotomi tersebut. 


\section{DAFTAR PUSTAKA}

Agama RI, Kementrian, Alquran Tajwid dan Terjemah, Cet: 9; Jawa Barat: CV Diponegoro, 2016.

al-'Usaimin, Muhammad bin Salih, Mustalah Al-Hadis, Cet: I;

Mesir al-'Arabiyah: Dar Ibnu Jauziyah al-Qohiroh, 2006.

al-Bukhari al-Ja'fiya, Muhammad bin Ismail Abu Abdillah, Lijami'

al-Sahih al-Mukhtasar (Sahih al-Bukhari), Juz I, Qairoh: al-

Muthabatu al-Salafiyyu wa al-Maktabatuha; Cetakan: I;

Tahun 1422.

al-Naisaburi, Muslim bin al-Hajjaj Abu al-Husain al-Qusyairi,

Sahi@h Muslim, Juz I, Cet. I; Saudiy, Riyad: Dar Taibah li

al-Nasyr wa al-Tawazzu', 1427 H/ 2006 M.

al-Sijistani, 'Abu Daud Sulaiman ibn al-'Asy'as ibn 'Ishaq ibn

Basyir ibn Syaddad ibn 'Amru al-'Azadi, Sunan 'Abi Daud, Juz II, Bairut: Jami' Haquq Hadzini al-Thaba'ah Mahfudzoh; Cetakan I; tahun $1418 \mathrm{H}$.

al-Tahan, Mahmud, Terj. Bahak Asadullah, Mustalah Al-Hadis:

Dasar-dasar Ilmu Hadits, Cet: II; Jakarta Timur: Ummul Qura, 2017.

ash-shiddieqy, Tengku Muhammad Hasbi, Sejarah Dan

Pengantar Ilmu Hadits, Cet;II: Semarang: PT Pustaka Rizki Putra, 2009.

Ibn Majah, Abi 'Abdullah Muhammad bin Yazid al-Quzwayniy aSyahir, Sunan Ibn Majah, Juz I, Cet. I ; Maktabah al-Ma'arif li al-Nashi wa al-Tawzi'I, Tahun 1417.

Idri, Hadis dan Orientalis, Cet: I; Depok: PT Balebat Dedikasi Perima, 2017.

Ismail, M. Syuhudi, Kaedah Kesahihan Hadis, Cet; II; Jakarta: PT Bulan Bintang, 1995.

Ismail, M. Syuhudi, Metode Penelitian Hadis Nabi, Cet: I; Jakarta: 
PT Bulan Bintang, 1992

Ismail, M. Syuhudi, Pengantar Ilmu Hadits, Cet: II; Bandung: Angkasa, 1994.

Marzuqi, Ahmad S, terjemahan Mushthalah Al Hadits, Cet:V; Jogjakarta: Media Hidayah, 2008.

Noorhidayati, Salamah, Kritik Teks Hadis, Cet: I; Yogyakarta: Dialektika, 2017.

Nur al-Din 'I, Terj. Mujiyo, Manhaj al-Naqad fi 'Ulum al-Hadis alNabawi: 'Ulum Hadis, Cet: V; Bandung: PT Remaja Sosdakarya, 2017.

Phoenix, Tim Pustaka, Kamus Besar Bahasa Indonesia, Cet: V; Jakarta Barat: PT Media Pustaka Phoenix, 2010.

Rahman, Fatchur ikhtishar Mushthalahu'l Hadits, Cet: I; Bandung: PT alm'arif, 1974.

Warson, Ahmad, Al Munawwir Kamus Arab-Indonesia Cet: II; Surabaya: Pustaka Progressif, 1997.

Yaqub, Ali Mustafa, Islam Masa Kini, Cet: I; Jakarta: Pustaka Firdaus, 2001.

Yaqub, Ali Mustafa, Kritik Hadis, Cet: VIII; Jakarta: Pustaka Firdaus, 2018.

Suhartinah, Dewi Anggraini dan Sitti, “Toleransi Antara Ummat Beragama Presfektif Alimustafa Yaqub", Studi Alquran Membangung Tradisi Berfikir Alquran14, no. 1, 2018. 